\title{
In vitro conservation of mangaba native to Brazilian Cerrado
}

\author{
Danyela Cristina Marques Pires ${ }^{1 *}$, Sabrina de Matos Trento ${ }^{1}$, Mariana Silva Pereira de Paula ${ }^{1}$, \\ Simone Abreu Asmar ${ }^{1}$, José Magno Queiroz Luz ${ }^{1}$, Ana Valéria Vieira de Souza²
}

\section{ABSTRACT}

\begin{abstract}
Mangaba (Hancornia speciosa var. gardneri) is a fruit tree of great social, economic and cultural importance in Brazil. Currently, it is threatened with extinction, so the Brazilian Ministry of the Environment has been encouraging the development of studies that can result in conservation strategies for this genetic resource. Thus, the objective of this work was to accomplish the slow-growth in vitro conservation of nodal segments of mangaba native to Brazilian Cerrado by changes in temperature and culture medium, and after that, to conduct the growth recovery of the explants. In the in vitro conservation stage, two experiments were made to test the temperatures of 25 and $20^{\circ} \mathrm{C}$, in which mangaba nodal segments were inoculated in transparent glass jars containing MS or WPM media at full or half strength, being evaluated at 45 and 90 days of in vitro conservation. In order to verify the growth recovery of the explants, these were transferred to multiplication medium, and evaluated at 60 days. Explants conserved at $20^{\circ} \mathrm{C}$ showed small and chlorotic leaves compared to those conserved at $25^{\circ} \mathrm{C}$. The reduction of the conservation temperature provided less development of the explants without affecting the survival rate. Explants conserved in WPM medium showed better responses to growth recovery. The results show that mangaba nodal segments conserved for 90 days on half-strength WPM medium and temperature of $20{ }^{\circ} \mathrm{C}$ presented slower growth and a good response to growth recovery stage.
\end{abstract}

Index terms: Hancornia speciosa; ex situ conservation; slow growth; biotechnology; tissue culture.

\section{INTRODUCTION}

Brazilian Cerrado is on the list of world biodiversity hotspots (Oliveira; Pietrafesa; Barbalho, 2008), because it is an area with high endemism and under strong threat of irreparable environmental losses (Myers et al., 2000). In 2011, despite the efforts to reduce deforestation, a loss of $997,063 \mathrm{~km}^{2}$ of Cerrado was recorded, which is equivalent to $48.89 \%$ of the biome total area (Brasil, 2015). The occupation and the disorderly exploitation of Brazilian Cerrado have caused the extinction of native species, the loss of genetic variability and the degradation of natural resources (Silva Júnior; Lédo, 2006).

Mangaba (Hancornia speciosa) is a fruit tree native to Brazil that has a great social, economic and cultural importance (Soares et al., 2006). Its fruits are nutritious and tasty, used for both fresh consumption and industry, where are widely used for juice and ice cream production (Oliveira et al., 2014). It also has medicinal properties. In the environmental aspect, it is suitable for the recovery of degraded areas and is a species capable of maintaining ecological relationships, since it is dispersed by fauna (Marinho et al., 2011; Soares et al., 2016; Silva Júnior et al., 2017).
However, mangaba is on the list of endangered species (Silva et al., 2012, 2017a, 2017b) and due to its importance, the Brazilian Ministry of the Environment has considered it one of the "Plants of the Future", a group of plants with a high priority for conservation, research and development in Brazil (Silva Júnior et al., 2018). Thus, there is a need to develop sustainable alternatives to conserve its genotypes and restore the species in its natural environment, which is fundamental for domestication and incorporation in the regional productive systems (Costa et al., 2011; Bezerra et al., 2014).

There are two basic in vitro conservation systems: slow growth, that limits growth to minimum rates; and cryopreservation, that totally suppresses cellular metabolism (Vieira, 2000). The slow-growth system provides short- and medium-term conservation, reducing the plant's metabolism without affecting its viability (Roca; Arias; Chavéz, 1991).

The object of the technique is to reduce plant growth and increase the intervals between subcultures by means of physical changes of the environment and/or chemical of the culture medium. Decreasing temperature is one of the most used strategies to reduce metabolic

Received in November, 2019 and approved in April, 2020

${ }^{1}$ Universidade Federal de Uberlândia/UFU, Instituto de Ciências Agrárias, Uberlândia, MG, Brasil

${ }^{2}$ Empresa Brasileira de Pesquisa Agropecuária/Embrapa Semiárido, Petrolina, PE, Brasil

${ }^{*}$ Corresponding author: danyelapires@yahoo.com.br 
activity and, consequently, explant growth (Lemos et al., 2002; Lédo et al., 2007; Moosikapala; Te-Chato, 2010; Engelmann, 2011).

Generally, the temperature of $4{ }^{\circ} \mathrm{C}$ is used for temperate crops and between 10 and $15^{\circ} \mathrm{C}$ for tropical crops (Keller et al., 2006), but this depends on the requirements of each species. Temperature control can also be combined with other factors such as the reduction of light intensity, the addition of plant regulators/osmotic agents or the suppression and/or reduction of nutrients available in the culture medium (Sánchez-Chiang; Jiménez, 2010; Silva et al., 2016).

Studies with slow-growth in vitro conservation have been developed and have shown viability for different native and tropical species, such as jenipapo (Genipa americana) (Lédo et al., 2015; Figueiredo et al., 2018), mangaba (Hancornia speciosa) native to Brazilian Northeast (Lédo et al., 2011), algodão-do-campo (Cochlospermum regium) (Camillo et al., 2009), coconut (Cocos nucifera) (Lédo et al., 2007), banana (Musa spp.) (Oliveira et al., 2000) and açaí (Euterpe oleracea) (Oliveira et al., 2001).

The establishment and improvement of in vitro conservation protocols for mangaba native to Brazilian Cerrado is necessary as responses may vary depending on the species and type of explant. Therefore, the objective of this work was to accomplish the slow-growth in vitro conservation of nodal segments of mangaba native to Brazilian Cerrado by changes in temperature and culture medium, and after that, to conduct the growth recovery of the explants.

\section{MATERIAL AND METHODS}

The work was carried out at the Biotechnology Laboratory of the Federal University of Uberlândia. In laminar air flow cabinet, mangaba (Hancornia speciosa var. gardneri) nodal segments of approximately $1 \mathrm{~cm}$ in length were extracted from in vitro germinated plants and then inoculated into transparent glass jars, sealed by plastic lids, containing $40 \mathrm{~mL}$ of culture medium supplemented with $7 \mathrm{~g} \mathrm{~L}^{-1}$ agar and $\mathrm{pH}$ adjusted to 5.7. The jars were autoclaved at $121{ }^{\circ} \mathrm{C}$ for 20 minutes, one day before the inoculation.
Two experiments were conducted in growth room to test the temperatures of 25 and $20 \pm 2{ }^{\circ} \mathrm{C}$, in which were evaluated four culture media consisted of MS (Murashige; Skoog, 1962) and WPM (Lloyd; Mccown, 1980) at full- and half-strength salts, including the sucrose indicated by the authors for each medium. For each treatment, five replicates and four jars per replication, in completely randomized design and split-plot in time (45 and 90 days) were used. The jars were maintained in photoperiod conditions of 16 hours of light provided by $20 \mathrm{~W}$ white fluorescent light bulbs and evaluations were made at 45 and 90 days of in vitro conservation, observing the survival rate and the number of green leaves.

After 90 days of in vitro conservation, the explants were transferred to jars containing $40 \mathrm{~mL}$ MS medium, $30 \mathrm{~g} \mathrm{~L}^{-1}$ sucrose, $7 \mathrm{~g} \mathrm{~L}^{-1}$ agar, $1 \mathrm{mg} \mathrm{L}^{-1}$ 6-benzilaminopurina (BAP), $1 \mathrm{mg} \mathrm{L}^{-1}$ 1-naphthaleneacetic acid (NAA), $2 \mathrm{~g} \mathrm{~L}^{-1}$ activated charcoal and $\mathrm{pH}$ adjusted to 5.7 , which were previously autoclaved at $121^{\circ} \mathrm{C}$ for 20 minutes and, after inoculation, maintained in growth room at a temperature of $25 \pm 2{ }^{\circ} \mathrm{C}$ and photoperiod of 16 hours of light provided by $20 \mathrm{~W}$ white fluorescent light bulbs. The evaluation occurred at 60 days of growth recovery, observing the survival rate, number of green leaves, number of nodes, shoot length and fresh mass.

The data were tested for the assumptions of normality and homogeneity of variance by ShapiroWilk and Levene tests, respectively, at 1\% probability, by means of SPSS statistical software (IBM, 2013). The variables were submitted to analysis of variance and the means were compared by Tukey test using the software SISVAR (Ferreira, 2014). The influence of temperature was evaluated by combined analysis of the experiments through GENES program (Cruz, 2013). The tests were performed at $5 \%$ probability.

\section{RESULTS AND DISCUSSION}

Regarding the in vitro conservation stage of mangaba nodal segments, the first experiment using the temperature of $25 \pm 2{ }^{\circ} \mathrm{C}$ showed a significant effect of the time for survival rate, which reduced $22.5 \%$ with the advance of in vitro conservation time. The number of green leaves of the explants was influenced by the 
interaction between culture medium and time, in which the WPM and MS media, both at half-strength, provided the lowest development without showing leaf senescence with the advance of time (Table 1).

Table 1 - Survival rate and number of green leaves of mangaba (Hancornia speciosa var. gardneri) nodal segments submitted to temperature of $25 \pm 2{ }^{\circ} \mathrm{C}$ and different culture media at 45 and 90 days of in vitro conservation ${ }^{1}$.

\begin{tabular}{ccccc}
\hline \multirow{2}{*}{ Culture medium } & \multicolumn{2}{c}{ Survival rate (\%) } & \multicolumn{2}{c}{$\begin{array}{c}\text { Number of green } \\
\text { leaves }\end{array}$} \\
\cline { 2 - 5 } & \multicolumn{2}{c}{ Time (days) } & \multicolumn{2}{c}{ Time (days) } \\
\cline { 2 - 5 } & 45 & 90 & 45 & 90 \\
\hline Full-strength MS & 76.00 & 43.00 & $2.48 \mathrm{aA}$ & $1.58 \mathrm{abB}$ \\
Half-strength MS & 55.00 & 45.00 & $1.08 \mathrm{aA}$ & $1.32 \mathrm{abA}$ \\
Full-strength WPM & 82.00 & 65.00 & $2.46 \mathrm{aA}$ & $2.82 \mathrm{aA}$ \\
Half-strength WPM & 80.00 & 50.00 & $1.04 \mathrm{aA}$ & $1.06 \mathrm{bA}$ \\
\hline Mean & $73.25 \mathrm{~A}$ & $50.75 \mathrm{~B}$ & 1.76 & 1.69 \\
\hline W, $\mathrm{F}_{\text {Lev. }}{ }^{2}$ & $\mathbf{0 . 9 6 1 ;} \mathbf{0 . 5 4 3}$ & $\mathbf{0 . 9 4 5 ;} \mathbf{0 . 7 5 2}$ \\
$\mathrm{CV}_{1 ;}$ CV $_{2}$ (\%) & $34.80 ; 25.60$ & $69.59 ; 25.55$
\end{tabular}

${ }^{1}$ Means followed by equal letters, lowercase in the columns and uppercase in the rows, do not differ by Tukey test at $5 \%$ probability. ${ }^{2} \mathrm{~W}$ and $\mathrm{F}_{\text {lev }}$ : Statistics of Shapiro-Wilk and Levene tests, values in boldface indicate residues with normal distribution and homogeneous variances, respectively, at $1 \%$ probability.

The second experiment using the temperature of $20 \pm 2{ }^{\circ} \mathrm{C}$ showed the same results in the analysis of variance as in the first experiment and coincidentally there was also a reduction of $22.5 \%$ in the survival rate with the advance of in vitro conservation time. However, the lowest development of the explants was observed with the use of full-strength MS and half-strength WPM (Table 2).

WPM and MS media show different responses in the in vitro development of explants. Since WPM medium presents $25 \%$ of the concentrations of nitrate and ammonia ions of MS medium, besides of more potassium and a high level of sulfate ions, it has been specially developed for woody species (Pasqual, 2001), such as mangaba. Similar to this work, Camillo et al. (2009) obtained the minimal growth of algodão-do-campo (Cochlospermum regium) when the explants were submitted to half-strength WPM medium and temperature of $20^{\circ} \mathrm{C}$.
Table 2 - Survival rate and number of green leaves of mangaba (Hancornia speciosa var. gardneri) nodal segments submitted to temperature of $20 \pm 2{ }^{\circ} \mathrm{C}$ and different culture media at 45 and 90 days of in vitro conservation ${ }^{1}$.

\begin{tabular}{ccccc}
\hline \multirow{2}{*}{ Culture medium } & \multicolumn{2}{c}{ Survival rate (\%) } & \multicolumn{2}{c}{$\begin{array}{c}\text { Number of green } \\
\text { leaves }\end{array}$} \\
\cline { 2 - 5 } & \multicolumn{2}{c}{ Time (days) } & \multicolumn{2}{c}{ Time (days) } \\
\cline { 2 - 5 } & 45 & 90 & 45 & 90 \\
\hline Full-strength MS & 96.00 & 68.00 & $1.06 \mathrm{aA}$ & $1.06 \mathrm{bA}$ \\
Half-strength MS & 80.00 & 50.00 & $2.20 \mathrm{aA}$ & $1.20 \mathrm{abB}$ \\
Full-strength WPM & 87.00 & 70.00 & $2.54 \mathrm{aA}$ & $3.16 \mathrm{aA}$ \\
Half-strength WPM & 90.00 & 75.00 & $1.76 \mathrm{aA}$ & $2.56 \mathrm{abA}$ \\
\hline Mean & $88.25 \mathrm{~A}$ & $65.75 \mathrm{~B}$ & 1.89 & 1.99 \\
\hline W, $\mathrm{F}_{\text {Lev. }}{ }^{2}$ & $\mathbf{0 . 9 5 7 ;} \mathbf{0 . 9 5 6}$ & $\mathbf{0 . 9 4 8 ;} \mathbf{1 . 5 2 4}$ \\
CV $_{1 ;}$ CV $_{2}$ (\%) & $27.55 ; 15.33$ & $74.17 ; 34.06$ \\
\hline
\end{tabular}

${ }^{1}$ Means followed by equal letters, lowercase in the columns and uppercase in the rows, do not differ by Tukey test at $5 \%$ probability. ${ }^{2} \mathrm{~W}$ and $\mathrm{F}_{\text {lev }}$.: Statistics of Shapiro-Wilk and Levene tests, values in boldface indicate residues with normal distribution and homogeneous variances, respectively, at $1 \%$ probability.

When comparing the two experiments of in vitro conservation, it was verified in the analysis of variance a significant effect of the temperature for survival rate and no significant effect for number of green leaves. However, according to Tukey test, the survival rates at 25 and $20^{\circ} \mathrm{C}$ were statistically the same, and the leaves exhibited by explants conserved at $20^{\circ} \mathrm{C}$ were small and yellow (Table 3 and Figure 1 ). This indicates that the reduction of the in vitro conservation temperature provided slower growth of the mangaba explants.

Table 3-Influence of temperature on the survival rate and number of green leaves of mangaba (Hancornia speciosa var. gardneri) nodal segments submitted to different culture media at 45 and 90 days of in vitro conservation ${ }^{1}$.

\begin{tabular}{ccc}
\hline Temperature $\left({ }^{\circ} \mathrm{C}\right)$ & Survival rate $(\%)^{*}$ & Number of green leaves ${ }^{\mathrm{ns}}$ \\
\hline 25 & $62.00 \mathrm{a}$ & $1.73 \mathrm{a}$ \\
20 & $77.00 \mathrm{a}$ & $1.94 \mathrm{a}$ \\
\hline
\end{tabular}

${ }^{1}$ Means followed by equal letters, in the columns, do not differ by Tukey test at $5 \%$ probability. *Significant and ${ }^{\mathrm{ns}}$ not significant by $\mathrm{F}$ test at $5 \%$ probability. 

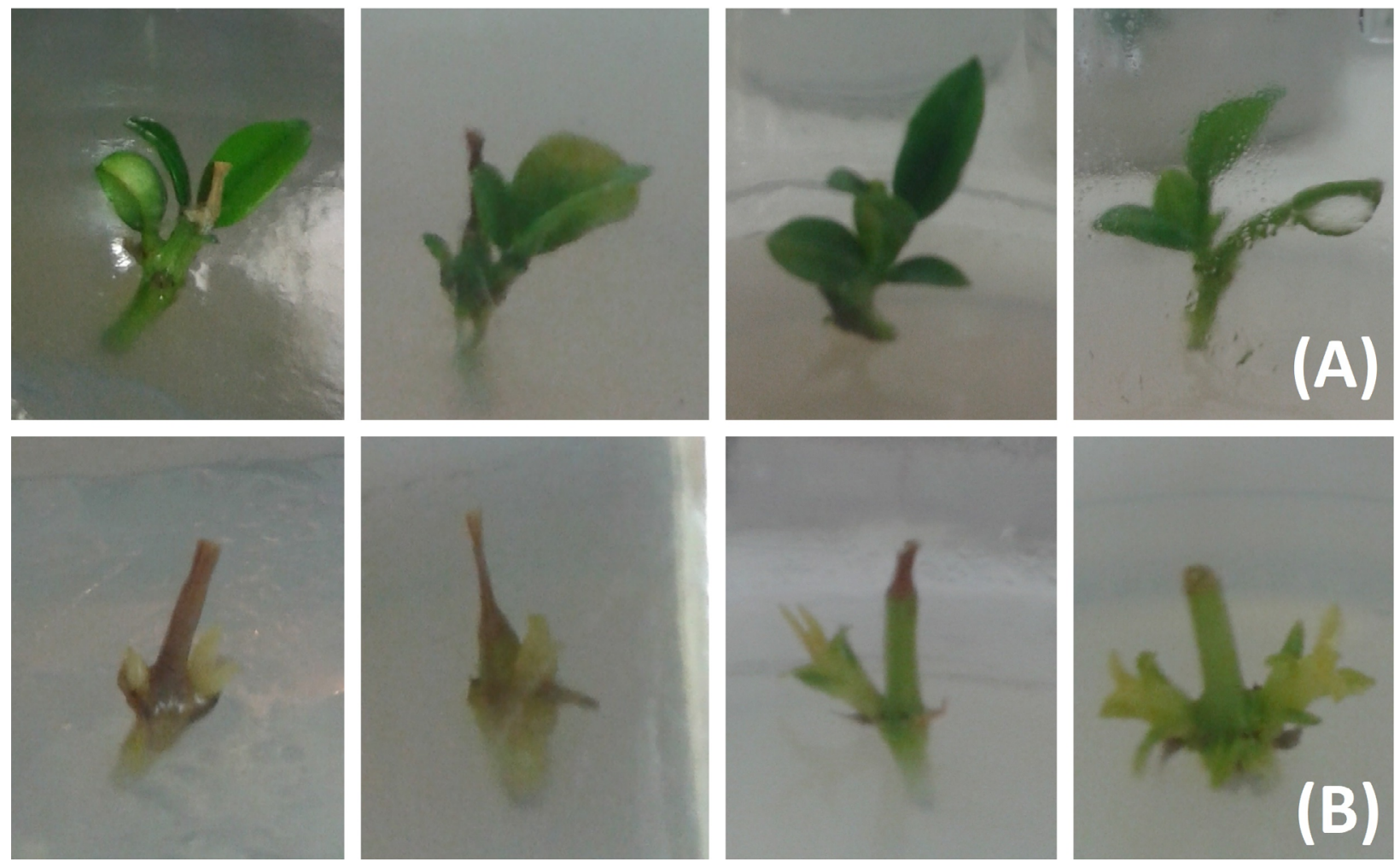

Figure 1 - Mangaba (Hancornia speciosa var. gardneri) nodal segments conserved for 90 days, at temperatures of $25^{\circ} \mathrm{C}$ (A) and $20^{\circ} \mathrm{C}(\mathrm{B})$, in full-strength MS, half-strength MS, full-strength WPM and half-strength WPM media, respectively.

Similarly, Oliveira et al. (2000) verified that, at the first 90 days of in vitro conservation, banana (Musa spp.) seedlings exhibited more yellowing leaves when maintained at temperatures below $17^{\circ} \mathrm{C}$, however, its in vitro conservation was obtained for 450 days.

Heat and cold are thermodynamic states characterized by the high or low kinetic energy of the molecules. In this way, the heat accelerates the movement of the molecules, which weakens the bonds between them, making the lipid layers of the biomembranes more fluid. The cold reduces the speed of the plant's vital chemical reactions, which makes biomembranes more rigid, requiring more energy to activate biochemical processes (Larcher, 2006). Thus, the cold reduces the plant development and causes the yellowing of the leaves, since the chloroplast is affected, causing damage to the photosynthetic apparatus and to the chlorophyll molecule (Sthapit; Witcombe; Wilson, 1995), which explains the formation of minor and chlorotic leaves.
According to Figueiredo et al. (2018), evaluating just the explants survival is not enough, since it is necessary to resume growth after the conservation stage. Therefore, the recovery stage is critical during the development of a slow-growth protocol and there is a need to assess the percentage of explants regenerated.

Regarding the growth recovery stage of mangaba explants performed after 90 days of in vitro conservation, on MS medium supplemented with BAP, NAA and activated charcoal, the interaction between culture medium and temperature showed no significant effect for any of the evaluated characteristics, unlike the isolated action of the culture medium which influenced all variables. In addition, according to the analysis of variance there was a significant effect of the temperature for shoot length, although this characteristic did not differ by Tukey test within the temperatures tested (Table 4). 
Table 4 - Survival rate (SR), number of green leaves (NGL), number of nodes (NN), shoot length (SL) and fresh mass (FM) of mangaba (Hancornia speciosa var. gardneri) nodal segments conserved in different temperatures and culture media at 60 days of growth recovery on MS medium supplemented with BAP, NAA and activated charcoal ${ }^{1}$.

\begin{tabular}{|c|c|c|c|c|c|}
\hline Culture medium during conservation stage & $\mathrm{SR}(\%) *$ & NGL * & $\mathrm{NN} *$ & $\mathrm{SL}(\mathrm{cm}) *$ & $\mathrm{FM}(\mathrm{g}) *$ \\
\hline Full-strength MS & $9.50 b$ & $0.28 \mathrm{~b}$ & $0.11 b$ & $0.04 b$ & $0.007 b$ \\
\hline Half-strength MS & $17.50 \mathrm{~b}$ & $0.43 b$ & $0.18 \mathrm{~b}$ & $0.16 \mathrm{~b}$ & $0.009 b$ \\
\hline Full-strength WPM & $49.50 \mathrm{a}$ & $3.41 \mathrm{a}$ & $1.23 a$ & $1.04 a$ & $0.038 a$ \\
\hline Half-strength WPM & $52.50 a$ & $2.37 a b$ & $0.59 a b$ & $0.45 a b$ & $0.026 a b$ \\
\hline Temperature $\left({ }^{\circ} \mathrm{C}\right)$ during conservation stage & $\mathrm{SR}(\%)^{\text {ns }}$ & NGL ${ }^{\text {ns }}$ & $\mathrm{NN}^{\mathrm{ns}}$ & $\mathrm{SL}(\mathrm{cm})^{*}$ & $\mathrm{FM}(\mathrm{g})^{\mathrm{ns}}$ \\
\hline 25 & $29.75 a$ & $1.38 \mathrm{a}$ & $0.60 \mathrm{a}$ & $0.58 \mathrm{a}$ & $0.21 \mathrm{a}$ \\
\hline 20 & $34.75 a$ & $1.86 a$ & $0.45 a$ & $0.26 \mathrm{a}$ & $0.19 a$ \\
\hline $\mathrm{W}^{2}$ & 0.918 & 0.945 & 0.949 & 0.872 & 0.879 \\
\hline $\mathrm{F}_{\text {Lev. }}^{2}$ & 3.842 & 2.303 & 6.177 & 2.591 & 1.349 \\
\hline $\mathrm{CV}(\%)$ & 54.92 & 36.54 & 98.85 & 115.31 & 73.77 \\
\hline Transformation & - & $\sqrt{x+0.5}$ & - & - & - \\
\hline
\end{tabular}

${ }^{1}$ Means followed by equal letters, in the columns, do not differ by Tukey test at $5 \%$ probability. ${ }^{2} \mathrm{~W}$ and $\mathrm{F}_{\text {lev }}$. : Statistics of ShapiroWilk and Levene tests, values in boldface indicate residues with normal distribution and homogeneous variances, respectively, at $1 \%$ probability. ${ }^{*}$ Significant and ${ }^{\mathrm{ns}}$ not significant by $\mathrm{F}$ test at $5 \%$ probability.

Mangaba nodal segments conserved in WPM medium exhibited better responses to growth recovery than those conserved in MS medium. However, although the WPM medium at full and half strength provided results statistically equal, the first one was superior since all the characteristics, with the exception of survival rate, differed from those of nodal segments developed in MS medium, regardless the salt concentration, unlike the second one (Table 4).

Although during growth recovery stage the MS medium was used for all treatments, these results are a reflection of the in vitro conservation stage, in which there was a tendency for explants conserved in WPM medium to present a higher survival rate in relation to those preserved in MS medium. So, it can be inferred that WPM medium is more suitable for the mangaba explants development.

Similarly, the woody plants louro-pardo (Cordia trichotoma) (Fick et al., 2007) and purple ipê (Handroanthus impetiginosus) (Bassegio et al., 2017) showed better in vitro development when cultivated in WPM medium.

\section{CONCLUSIONS}

To perform the medium-term conservation of mangaba native to Brazilian Cerrado, it is possible to use the slow-growth technique for up to 90 days. For this, nodal segments must be conserved on half-strength WPM medium at temperature of $20^{\circ} \mathrm{C}$.

\section{ACKNOWLEDGMENTS}

To Capes, in partnership with Embrapa Semiárido, for the financial support.

\section{REFERENCES}

BRASIL. Ministério do Meio Ambiente. Instituto Brasileiro do Meio Ambiente e dos Recursos Naturais. Monitoramento do Desmatamento nos Biomas Brasileiros por Satélite: Cerrado 2010-2011. Brasília, 2015. 16p.

BASSEGIO, C. et al. Desenvolvimento de ipê-roxo em meios de cultura e concentrações de bap (6-benzilaminopurna) durante a etapa de multiplicação in vitro. Acta Iguazu, 6(1):72-80, 2017.

BEZERRA, R. M. de F. et al. Efeito de 6-benzilaminopurina sobre a propagação in vitro de Mimosa caesalpiniifolia Benth. (Fabaceae). Revista Árvore, 38(5):771-778, 2014.

CAMILLO, J. et al. Conservação in vitro de Cochlospermum regium (Schrank) Pilg.- Cochlospermaceae sob regime de crescimento mínimo. Revista Brasileira de Plantas Medicinais, 11(2):184-189, 2009. 
COSTA, T. S. et al. Diversidade genética de acessos do banco de germoplasma de mangaba em Sergipe. Pesquisa Agropecuária Brasileira, 46:499-508, 2011.

CRUZ, C. D. GENES - A software package for analysis in experimental statistics and quantitative genetics. Acta Scientiarum. Agronomy, 35(3):271-276, 2013.

ENGELMANN, F. Use of biotechnologies for the conservation of plant biodiversity. In Vitro Cellular \& Developmental Biology Plant, 47(1):5-16, 2011.

FERREIRA, D. F. Sisvar: A Guide for its Bootstrap procedures in multiple comparisons. Ciência e Agrotecnologia, 38(2):109112, 2014.

FICK, T. A. et al. Estabelecimento e crescimento in vitro de plântulas de louro-pardo. Ciência Florestal, 17(4):343-349, 2007.

FIGUEIREDO, J. R. M. et al. Conservação de Genipa americana: Técnicas de encapsulamento e crescimento lento. Revista da Universidade Vale do Rio Verde, 16(1):1-9, 2018.

IBM CORP. IBM SPSS Statistics for Windows, Version 22.0. Armonk, NY: IBM Corp, 2013.

KELLER, E. R. J. et al. Slow growth storage and cryopreservation: Tools to facilitate germplasm maintenance of vegetatively propagated crops in living plant collections. International Journal of Refrigeration, 29:411-417, 2006.

LARCHER, W. Ecofisiologia Vegetal, São Carlos: Rima, 2006. $398 p$.

LÉDO, A. da S. et al. Efeito da sacarose e do manitol na conservação in vitro por crescimento lento do coqueiro anão. Magistra, 19:346-351, 2007.

LÉDO, A. da S. et al. Protocolo para conservação in vitro por crescimento lento de mangabeira (Hancornia speciosa Gomes). Aracaju, SE: Embrapa Tabuleiros Costeiros, 2011. 4p. (Comunicado Técnico, 115).

LÉDO, A. da S. et al. Medium-term conservation and regrowth of the tropical multipurpose species Genipa americana. African Journal of Agricultural Research, 10(41):38853892, 2015.

LEMOS, E. E. P. et al. Conservação in vitro de germoplasma de cana-de-açúcar. Pesquisa Agropecuária Brasileira, 37(10):1359-1364, 2002
LLOYD, G.; MCCOWN, B. Commercially-feasible micropropagation of mountain laurel, Kalmia latifolia, by use of shoot tip culture. International Plant Propagators Society Proceedings, 30:421-427, 1980.

MARINHO, D. G. et al. The latex obtained from Hancornia speciosa Gomes possesses anti-inflammatory activity. Journal of Ethnopharmacology, 135(2):530-537, 2011

MOOSIKAPALA, L.; TE-CHATO, S. Application of in vitro conservation in Vetiveria zizanioides Nash. Journal of Agricultural Technology, 6(2):401-407, 2010.

MURASHIGE, T.; SKOOG, F. A revised medium for rapid growth and bio assays with tobacco tissue cultures. Physiologia Plantarum, 15(3):473-497, 1962.

MYERS, N. et al. Biodiversity hotspots for conservation priorities. Nature, 403:853-858, 2000.

OliveirA, D. A.; PIETRAfesA, J. P.; BARBALho, M. G. S. Manutenção da biodiversidade e o hotspots Cerrado. Caminhos de Geografia, 9(26):101-114, 2008.

OLIVEIRA, K. S. de et al. Efeito de diferentes meios de cultura na germinação in vitro de sementes de mangabeira (Hancornia speciosa Gomes). Revista Árvore, 38(4):601-607, 2014.

OLIVEIRA, M. S. P. et al. Viabilidade de pólen in vivo e in vitro em genótipos de açaizeiro. Acta Botânica Brasilica, 15(1):2733, 2001.

OLIVEIRA, R. P. et al. In vitro conservation of diploid banana accessions. Scientia Agricola, 57(2):245-249, 2000.

PASQUAL, M. Textos acadêmicos: Meios de cultura. Lavras: FAEPE/UFLA, 2001. 127p.

ROCA, W. M.; ARIAS, D. I.; CHAVÉZ, R. Métodos de conservación in vitro del germoplasma. In: ROCA, W. M.; MROGINSKI, L. A. (Ed.). Cultivo de tejidos en la agricultura: Fundamentos y aplicaciones. Cali: Centro Internacional de Agricultura Tropical, 1991, p.969.

SÁNCHEZ-CHIANG, N.; JIMÉNEZ, V. M. Técnicas de conservación in vitro para el establecimiento de bancos de germoplasma en cultivos tropicales. Agronomía mesoamericana. 2(1):193-205, 2010.

SILVA, A. V. C. et al. Genetic diversity analysis of mangaba (Hancornia speciosa Gomes), an exotic Brazilian tropical species. Tropical and Subtropical Agroecosystems, 15(2):217-225, 2012. 
SILVA, A. V. C. et al. Genetic diversity of remaining populations of mangaba (Hancornia speciosa Gomes) in restingas of Brazil. Journal of Agricultural Science, 9(2):46-52, 2017a.

SILVA, A. V. C. et al. Uses and technological prospects for the mangaba, a native fruit of Brazil. African Journal of Biotechnology, 16(7):302-311, $2017 \mathrm{~b}$.

SILVA, N. D. G. et al. Conservação in vitro de amoreira-preta: Crescimento lento. Plant Cell Culture and Micropropagation, 12(1):7-12, 2016.

SILVA JÚNIOR, J. F. da; LÉDO, A. S. (Ed.). Botânica. In: SILVA JÚNIOR, J. F.; LÉDO, A. S. (Ed.). A cultura da mangaba. Aracaju: Embrapa Tabuleiros Costeiros, 2006. p.25-33.

SILVA JÚNIOR, J. F. da et al. Mangaba: Hancornia speciosa Gomes. PROCISUR: Instituto Interamericano de Cooperación para la Agricultura (IICA), 2017. 27p.
SILVA JÚNIOR, J. F. da et al. Descriptors for Mangaba (Hancornia speciosa Gomes). Bioversity International, Rome, Italy and Brazilian Agriculture Research Corporation, Embrapa Tabuleiros Costeiros, Aracaju, SE, Brazil, 2018. 56p.

SOARES, F. P. et al. Cultura da mangaba (Hancornia speciosa Gomes). Boletim Agropecuário, 67:1-12, 2006.

SOARES, A. N. R. et al. Genetic diversity in natural populations of mangaba in Sergipe, the largest producer State in Brazil. Genetic and Molecular Research, 15(3):1-12, 2016.

STHAPIT, B. R.; WITCOMBE, J. R.; WILSON, J. M. Methods of selection for chilling tolerance in Nepalese rice by chlorophyll fluorescence analysis. Crop Science, 35(1):90-94, 1995.

VIEIRA, M. L. C. Conservação de germoplasma in vitro. Biotecnologia Ciência \& Desenvolvimento, 3(14):18-20, 2000. 